\title{
VALORIZATION OF NATURAL TOURIST POTENTIALS AND THEIR PROTECTION IN THE PODRINJE TOURIST-GEOGRAPHICAL REGION
}

\author{
Aida Bidžan-Gekić ${ }^{1}$ \\ Haris Gekić \\ Lejla Žunić \\ Senada Nezirović ${ }^{4}$
}

\begin{abstract}
Podrinje tourist-geographical region is rich in diversity and preserved from pollution natural tourist potentials that can be the basis for the development of more specific forms of tourism (mountain, hunting, rural, excursion-recreational, adventure, recreational-sports, fishing, and ecotourism), both local and of regional, national or international importance. This paper will present the most important natural tourist potentials of the Podrinje touristgeographical region, their valorization, as well as their possibility of use for tourist purposes. Also, the tourist traffic and accommodation capacities of this tourist-geographical region will be shown. Finally, a conclusion will be given as to how these unique, still unspoiled natural phenomena, should be treated so that they remain so for future generations.
\end{abstract}

Keywords: Podrinje tourist-geographical region, natural tourist potentials, tourist valorization, tourist development.

\section{INTRODUCTION}

This paper aims to give an overview of all-natural tourist potentials of Podrinje touristgeographical region, the possibility of their valorization, which would contribute to its economic development, but in a way that would allow these development plans and their implementation to not disturb the geoecological balance, i.e only develop those forms of tourism that are nature-friendly.

The resource basis of modern tourism in the Podrinje tourist-geographical region must be methodologically processed based on geographical, economic, and socio-cultural research, to be able to make a complete tourist offer. The following general and special methods of regional-geographical research will be used in this paper: method of regional-geographical analysis and synthesis of tourist-geographical factors, method of homogeneity in the spatial distribution of tourist-geographical parameters to identify the tourist-geographical potential of Podrinje tourist-geographical region, then the method of determining the spatial-functional connections and relations, primarily

\footnotetext{
${ }^{1}$ Department of Geography, Faculty of Science, University of Sarajevo, Zmaja od Bosne 35, 71 000 Sarajevo, Bosnia and Herzegovina, Email: aidabidzan@gmail.com

2 Department of Geography, Faculty of Science, University of Sarajevo, Zmaja od Bosne 35, 71 000 Sarajevo, Bosnia and Herzegovina, Email: hgekic@ gmail.com

3 Department of Geography, Faculty of Science, University of Sarajevo, Zmaja od Bosne 35, 71 000 Sarajevo, Bosnia and Herzegovina, Email: pmflejlazunic@yahoo.com

${ }^{4}$ Department of Geography, Faculty of Science, University of Sarajevo, Zmaja od Bosne 35, 71 000 Sarajevo, Bosnia and Herzegovina, Email: senadanezirovic@yahoo.com
} 
conditioned by the tourist activity, to develop them as well as possible, and to disturb the natural environment as little as possible.

During the process of evaluation of natural tourist potentials, different touristgeographical methods and valorization factors will be applied, whereby a very complex classification procedure (identification and analysis of attractive properties, spatial coverage, distribution, etc.) and categorization/ranking of tourist potentials will be performed (according to the importance, seasonality, complementarity, etc.). Natural tourism potentials are then separated into two groups, namely, real and potential tourism potentials. During the evaluation, special attention was paid to their complementarity, the suitability of their tourist-geographical position concerning emitting markets, tourist directions, and competitive receptive areas, as well as existing and potential roads, which enable accessibility from emitting areas, etc.

This detailed and complex analysis, classification, and categorization of natural tourism potentials is made possible thanks to the used professional and scientific literature, which consisted of spatial plans at the state, entity, cantonal and municipal level, development plans and strategies (economic and tourism) of cantons and municipalities, the official websites of municipalities and tourist boards, as well as own field research.

\section{PODRINJE TOURIST-GEOGRAPHICAL REGION}

Podrinje tourist-geographical region is located in eastern Bosnia and covers an area of $6,225 \mathrm{~km}^{2}$. Its tourist-geographical position is favorable, because it connects the central parts of Bosnia and Herzegovina with the Republic of Serbia and the Republic of Montenegro, and through it, the East-Herzegovinian tourist-geographical region leads to Dubrovnik (Croatia), which is another advantage of its position, which would be even more favorable if the quality of those roads was improved.

It includes the following municipalities: Goražde, Novo Goražde, Istočna Ilidža, Istočni Stari Grad, Istočno Novo Sarajevo, Pale (FBiH), Kalinovik, Foča, Foča (FBiH), Čajniče, Pale, Šekovići, Sokolac, Rogatica, Rudo, Han Pijesak, Višegrad, Vlasenica, Milići, Zvornik, Srebrenica and Bratunac. This region is polycentric and its tourist centers are Foča, Goražde and Višegrad. According to preliminary data from the 2013 census, it has 257,360 inhabitants, and its population density is 180 inhabitants $/ \mathrm{km}^{2}$ (Bidžan, A., 2011, 2012; http://fzs.ba/ index.php/popis-stanovnistva/popisstanovnistva-2013/konacni-rezultati-popisa-2013/).

The Podrinje region extends at an altitude of 130 - 2,368 m. It has many significant geomorphological tourist potentials: Maglić, Zelengora, Lelija, Jahorina, Romanija, Treskavica, Devetak, and Javor. At lower altitudes, a moderately warm and humid climate prevails, and at higher altitudes, a forest-snow and tundra climate prevails. Average annual air temperatures range from 2 - 100C, and average annual rainfall from $800-1,750 \mathrm{~mm}$. In the hydrographic sense, it is adorned by the rivers Tara and Drina (Fig.1) and its tributaries: Prača, Kolina, Ćehotina, Kosovska rijeka, Lim, etc. which abound in rich fish stock and are a real atmosphere for anglers, also because of the still unpolluted water attract in the warm months a large number of bathers (Atlas of the World for primary and secondary school, 1998). Huchen from Drina is famous for its weight of up to 37 kilograms, and trout and other species of river fish are also attractive, which makes fishing tourism on the rise. In the biogeographical sense, this area includes 
the following ecosystems: dark coniferous forests, Pančić spruce, thermophilic forests with malt, juniper pine, mountain ores on carbonates, and beech-fir forests (Lakušić, R., 1981).

Archaeological excavations confirm that the area of the Podrinje tourist-geographical region was inhabited during the Stone Age and the Roman period, but more intensive settlement began in the Middle Ages, as evidenced by many traces, including numerous Bogumil cemeteries, settlements, and toponyms. In this period, the most memorable ruler is Stjepan Vukčić Kosača, who in 1437 completely broke away from the Bosnian king and independently ruled this realm until his death in 1466. In 1448, he received the title of Herzog (Herceg), making him popularly known as Herceg Stjepan. Since then, the area managed by Herceg Kosača has been named Herzegovina. He was the last ruler of this area based in Sombor near Goražde. With the arrival of the Ottomans in this area, Goražde became a nahiye of the Foča kadiluk, and Foča (Hoča) is a significant town with a developed craft and trade activity. Also, it is important to mention that in this area was the Herzegovina sanjak with its headquarters in Foča. This sanjak was initially divided into three smaller administrative areas that coincided with the kadiluks. The heritage from the Ottoman period is not so rich in Goražde, unlike Foča and Višegrad, which had numerous cultural and historical monuments, destroyed during the aggression on Bosnia and Herzegovina, and which are being restored to this day. During the Austro-Hungarian rule in the area of this region, the most significant changes occurred after the construction of the road Rogatica-Jabuka-Goražde in the length of 26 kilometers, which certainly contributed to the further development of this area (Živojević, R.S, 2009).

This region does not have numerous cultural and historical monuments, as already mentioned, but this small number that has been preserved belongs to the group of unique and very valuable anthropogenic tourist potentials, namely: Mehmed-pasha Sokolović Bridge in Višegrad, Dobrun Fortress in Višegrad, Kušlat Mosque in Zvornik, the Potočari Memorial Center in Srebrenica, the Memorial Center of the Battle of Sutjeska and numerous other religious objects and cultural buildings.

It is connected with the neighboring tourist-geographical regions by common natural tourist potentials, so it is connected with the Posavina region via the river Drina, with the Tuzla region via the river Spreča, with the Sarajevo region via Trebević and Treskavica, and with the East Herzegovina region via Zelengora (Bidžan, A., 2012).

The Podrinje tourist-geographical region is connected with the Tuzla region by the M19 highway, with the Sarajevo region via the M-19 and M-5 and M-18 highways, and with the East Herzegovina region and the Adriatic coast with the M-20 highway. Most of these roads are in poor condition, so they should be reconstructed urgently if this region has the intention to conduct tourism more seriously.

Regarding tourist traffic, the Podrinje tourist-geographical region in 2019 had 3.335 tourist arrivals, of which $93 \%$ were domestic tourists and $7 \%$ foreign tourists. They realized 7.203 overnight stays, of which domestic participated with 92\%, and foreign tourists with $8 \%$. Most tourists come from Croatia, Slovenia, Serbia, Germany, Austria, Italy, and Turkey (https://fzs.ba/wp-content/uploads/2020/06/BPK_2020.pdf, www.rzs.rs.ba).

Natural resources, extraordinary beauty, and diversity, such as beautiful forests, canyons, rivers, and mountains provide the opportunity for everyone to find something for themselves (timber rafting, rafting, kayaking, swimming, fishing, hiking, etc.), 
following their interests. In the area of the Podrinje region, several different economic, cultural, and sports events are organized, which aim to attract the attention of as many domestic and foreign tourists as possible.

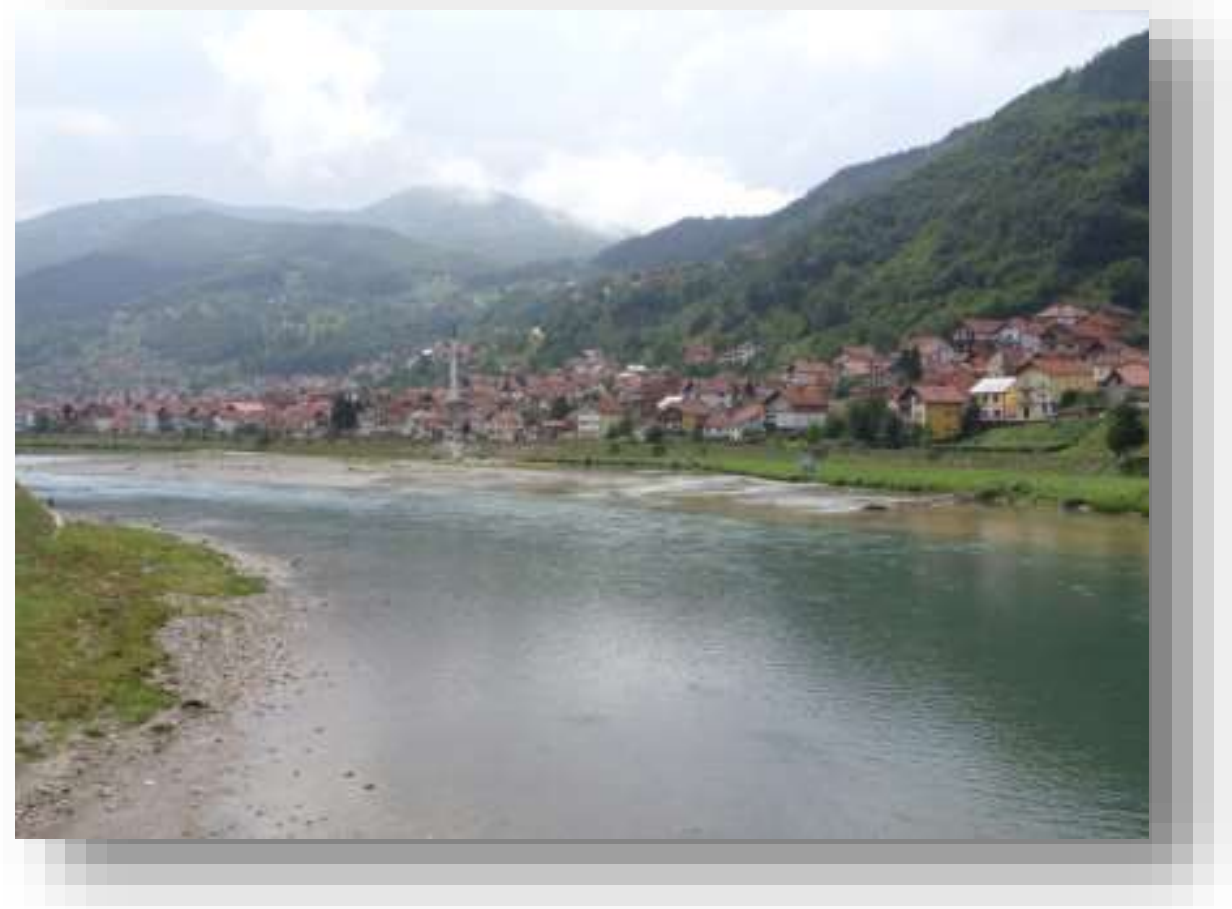

Figure 1: Drina River in Goražde

(Photo: Author)

The following events are held in the Town of Goražde: "Days of Apples" and "Days of Honey and Medicinal Herbs" are in the function of promoting and marketing fruit and fruit products, vegetables and vegetable products, and honey and medicinal plants. Also, there are numerous cultural events, such as "International Friendship Festival", "Days of Isak Samokovlija", "April Days of Culture", "What a Song Dreams of", etc. The international art colony "Colors of Friendship" and the sports event "Hunting for a Huchen" are held in Ustikolina (http://www.turizam-bpk.ba/page4.html ). There are also numerous events in the municipality of Foča: Auto-moto rally "Sutjeska", Drina adventure, Fair of cheese, honey, wines and traditional products, Days of blueberries and lakes Zelengora, OK fest, etc.

According to its functionality, this tourist-geographical region belongs to the group of regions for leisure and recreation. It has a very modest significance for defining the tourist offer of Bosnia and Herzegovina; out of a total of 626 national monuments in Bosnia and Herzegovina, in the Podrinje region there are only 36 national monuments, but its natural potentials, which are extraordinary beauty and diversity (beautiful forests, canyons, rivers, and mountains) provide the opportunity for everyone to find something for themselves (timber rafting, rafting, kayaking, swimming, fishing, hiking, etc.), according to their interests (Bidžan, A., 2015). In the area of the Podrinje region, several different economic, cultural, and sports events are organized, which aim to attract the 
attention of as many domestic and foreign tourists as possible, but due to poor marketing, they are still of a local character. Based on all that has been said, the following specific forms of tourism can be developed: bathing, fishing, hunting, cultural-manifestation, sports-recreational, adventure, eco-tourism, rural tourism, etc.

\section{Natural tourist potentials of the Podrinje tourist-geographical region}

Significant wealth and recognizability of the Podrinje tourist-geographical region are its natural beauties. Namely, this area abounds in many rivers, of which, among others, it is necessary to single out one of the most beautiful - the Drina River with numerous tributaries, larger or smaller watercourses, hot springs, caves, and forests that make exceptional landscape values. The natural values of this region are characterized by originality, diversity, and attractiveness, and the phenomenon of this area is, precisely, water and forests. In economic terms, the waters of the mentioned rivers certainly stand out, which, both in terms of quality and quantity, represent a significant potential for multipurpose use. We should especially emphasize that this region is adorned with unpolluted land, forests, and various landscapes rich in natural beauty, which is suitable for the development of various specific forms of tourism. It is also necessary to mention the valuable cultural and historical heritage, which complements these rare natural resources. In the following Table 1, we will give an overview of the most important natural tourist potentials of the Podrinje tourist-geographical region, as well as suggestions on which specific forms of tourism could be developed.

Table 1: The forms of tourism and most important natural tourist potentials of the Podrinje tourist-geographical region

\begin{tabular}{|c|c|c|c|}
\hline \multicolumn{3}{|c|}{ Natural tourist potentials } & The predominant \\
\hline \multirow[t]{12}{*}{ Geomorphological } & \multirow[t]{8}{*}{ Mountains } & Maglić & MT / HT / FT \\
\hline & & Zelengora & MT / HT / FT \\
\hline & & Lelija & $\mathrm{MT} / \mathrm{HT} / \mathrm{FT}$ \\
\hline & & Jahorina & MT / HT / FT \\
\hline & & Romanija & MT / HT / FT \\
\hline & & Treskavica & MT / HT / FT \\
\hline & & Devetak & MT / HT / FT \\
\hline & & Javor & $\mathrm{MT} / \mathrm{HT} / \mathrm{FT}$ \\
\hline & $\begin{array}{l}\text { Gorges and } \\
\text { canyons }\end{array}$ & Drine & ER / FT / ET /RST \\
\hline & Sand pyramids & Foča & ER \\
\hline & \multirow[t]{2}{*}{ Caves and pits } & Orlovača, Pale & SPT \\
\hline & & Peruc, Foča & SPT \\
\hline \multirow[t]{6}{*}{ Hydrographic } & \multirow[t]{6}{*}{ Rivers } & Drina & ET/RST/ FT/ECOT \\
\hline & & Tara & ET/RST/ FT/ECOT \\
\hline & & Ćehotina & FT \\
\hline & & Prača & FT \\
\hline & & Kolina & FT \\
\hline & & Lim & FT \\
\hline
\end{tabular}




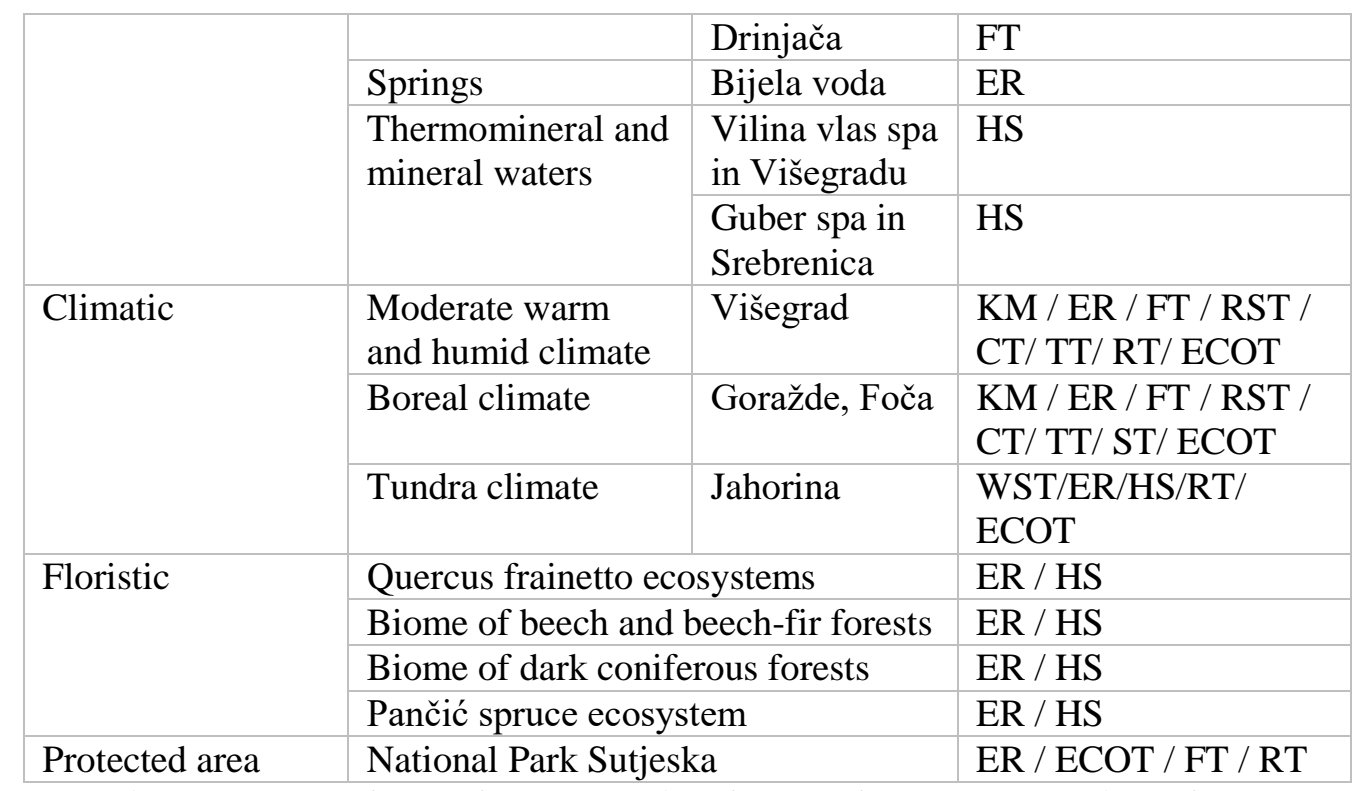

Legend: MT- mountain tourism; HT - hunting tourism; RT - rural tourism; ER excursion-recreational tourism, ET - extreme tourism; RST - recreational and sports; HS - health and spa tourism; FT - fishing tourism; SPT - speleological tourism; WST winter sports tourism; CT - congress tourism; TT - transit tourism; ECOT - ecotourism. Source: Bidžan, A., 2011.

As we can see from Table 1, the Podrinje tourist-geographical region is very rich in natural tourist potentials, and below we will describe the most important ones.

Jahorina mountain is located in the central part of Bosnia and Herzegovina, in a range of Dinaric mountains Čvrsnica, Prenj, Bjelašnica, Treskavica, and Zelengora. Sarajevo is the closest big city from which Jahorina can be reached via Pale $(28 \mathrm{~km})$ and via Trebević $(32 \mathrm{~km})$ by asphalt and well-cleaned roads in winter. Based on that, this mountain has a favorable tourist-geographical position. Jahorina is not only the most famous mountain tourist value of Bosnia and Herzegovina but also one of the most established and visited in our country, from the Olympics until after the war, when it gradually returned to its former glory and became a top winter sport and tourist center. This mountain is built mainly of Triassic limestone and dolomite with branches and is about $30 \mathrm{~km}$ long and about $15 \mathrm{~km}$ wide. The main tourist value of Jahorina is competition and tourist trails, trails for professionals and beginners, on wide, clear, and diverse slopes without mechanical obstacles where a quality snow cover, two to three meters thick, stays for about 180 days a year.

This mountain is ideal for the development of sports and recreational tourism. Tourists who enjoy skiing have at their disposal more than $20 \mathrm{~km}$ of groomed alpine ski trails with four lifts and four ski lifts, with a total capacity of 7,500 skiers per hour. Also, night skiing is becoming more and more popular on this mountain, with an increasing number of visitors every year, as well as cross-country skiing, snowboarding, and much more. The most suitable ski trails are located at altitudes between 1,600 and 1,880 meters. Specifically, it is the central part of the northern slopes of Jahorina, Gola Jahorina, about $15 \mathrm{~km}$ long and 4-5 km wide, which, together with the Rajska dolina, 
represents the most attractive tourist part of this mountain, especially for recreational and competitive skiing, and especially for alpine disciplines (http://www.jahorina.org/oc-jah.php).

In summer, tourists can walk the spacious pastures or pick forest fruits and herbs. Additionally, they can rent bicycles or small cars with an all-wheel drive, play tennis, football, basketball or simply sunbathe on one of the terraces of many restaurants and cafes. Jahorina has ten hotels, four boarding houses, and one facility with rooms for rent and together they have 2,859 beds, which is a small number of beds. If new accommodation facilities with a larger number of beds and numerous other accompanying facilities were built, this beauty would be even more attractive for tourists and the number of arrivals and overnight stays of foreign and domestic tourists would increase (http://www.jahorina.org/oc-jah.php).

Zelengora mountain is one of the pearls of the Sutjeska National Park. Although the highest peak of Zelengora is Bregoč with 2,014 meters, there also are a dozen other peaks of about 2,000 meters. Zelengora is covered with forests, pastures, flowery mountain fields, which is where its name comes from („The Green Mountain“). It has eight „mountain eyes“: Kotlaničko Lake, Orlovačko Lake, Štirinsko Lake, Jugovo Lake, Donje Bare, Gornje Bare, Crno Lake, Borilovačko Lake and Bijelo Lake. The road to the areas of Zelengora can start from Foča to Tjentište, through the villages of Vrbnica and Štavanj, passing by the Black Lake, which is located 1,500 meters, and then descending to the Bijelo Jezero, which is convenient even for bathing. Along the Foča-Gacko road, you can also go towards the heights of Zelengora, if you turn right on the Čemerno pass and continue on a not very good macadam road for $20 \mathrm{~km}$. This road leads to Orlovačko Lake, and there are marked paths towards Kotlaničko and Štirinsko lakes. By descending the slopes of Zelengora from there, you can see Borilovačko or Jugovo Lake. In front of Orlovačko Lake, a few hundred meters away, there is a hunting lodge, which is managed by the Sutjeska National Park. Access to these lakes is possible from the direction of Kalinovik, and the length of this road is approximately the same as from the direction of Čemerno (about $25 \mathrm{~km}$ ), but this road is in a much worse condition, because it transports the forest, so it is usually passable only for off-road vehicles. Zelengora is potentially the largest resort in the Balkans. In the future, ski centers will be built, to extend the tourist season in the winter months. Of the accommodation capacities, there are only hunting and mountain houses in four locations: Bogunovac, Dobre vode, Donje Bare, and Orlovačko lake with a total of 30 beds. Forest roads will be built preserving the mountain ecosystem, as well as recreation settlements (motels, ethno villages, ski centers) (http://www.zone2000.net/service/books_img/mag_vol_zel.pdf).

In the attractive localities of Zelengora and Lelija, there are mountain and hunting houses (Gornje Bare, Jugovo, and Borilovačko lakes, Jablan Do, Bijele vode, etc.) connected by mountain trails and macadam roads, which could be used for the development of hunting tourism. There are no mountaineering facilities on the mountains Maglić, Volujak, and Ljubišnja. They are located within the Sutjeska National Park, as well as the Perućica rainforest reserve with the Skakavac waterfall, 75 
$\mathrm{m}$ high, and they are most visited by mountaineers during the summer, which means that, with better marketing, mountain tourism could be developed. Hut settlements on Zelengora are also attractive and could be used for the development of rural and ecotourism (http://www.npsutjeska.net/stranica.phpid=51\&naziv=planine\&jez=bs).

$>\quad$ Drina Canyon is located in the Podrinje tourist-geographical region, which is also a complementary tourist potential (Bidžan, A., 2011). Due to its crooked flow, the saying "Nobody can set the crooked Drina straight" was created among the people. It often happened that it spilled out of its trough and on that occasion destroyed everything in front of it. In many places, the Drina passes through straits in which high rocks rise almost vertically from the water. The river Drina passes between the mountains Zvijezda and Tara, downstream from Višegrad, and it is here that its canyon is the deepest because some peaks rise over $1,000 \mathrm{~m}$.

The river Drina is formed by the confluence of the Montenegrin rivers Piva and Tara in Šćepan Polje at an altitude of $434 \mathrm{~m}$, from which place, their beauty and strength, flowed into the sparkling green river, Drina, then winding through the most beautiful canyons to the north. Not far from Sremska Rača, after 346 kilometers of flow, of which $220 \mathrm{~km}$ represents the border of Serbia and Bosnia and Herzegovina, Drina flows into the Sava River at an altitude of $78 \mathrm{~m}$. The average altitude of Drina per kilometer decreases by a little more than one meter, which makes it an extremely fast river (it is one of the fastest rivers in the Balkans). The width of the river flow varies from 100$200 \mathrm{~m}$ near Perućac and Zvornik to $15 \mathrm{~m}$ at a place called Tijesno. The average depth of the Drina is $3 \mathrm{~m}$, and a maximum of $12 \mathrm{~m}$. The average flow of the Drina is 370 $\mathrm{m}^{3} / \mathrm{sec}$. In the lower course, the Drina deposits large amounts of sand and gravel and builds many hells (around which it forks), reefs, shoals, meanders, and bends, which is why it is called the "Crooked Drina" (http://www.voders.org/index.php/slivovi/slivdrine; http://www.logosfera.net/reka-drina -i-njen-sliv/).

The whole area is overgrown with pine forest, which is home to many wild animals, and it is possible to see various species of birds, which have found refuge there. Thanks to these natural tourist features, this area is suitable for the development of the following specific forms of tourism: eco-tourism, adventure (free climbing, canyoning, kayaking, canoeing, rafting), hunting, excursions, and scientific research.

The upper course of the river Drina is still preserved from all pollutants, which is the basic precondition for the existence of the most interesting salmonid fish species, interesting to fishing connoisseurs. The mountain river Prača, a gift of untouched nature, represents a unique wealth of autochthonous brown trout and capital specimens of grayling. Favorable terrain configuration, appropriate climate, and forest resources are the main factors of several hunting areas in the area, of which we single out the largest in Bosnia and Herzegovina, "Kriva Draga"(,Crooked Darling“), which includes the hunting complex Bijele vode (White Waters) with a containment area equipped for the training of hunting dogs (http://www.turizam-bpk.ba/page6.html).

Unique in Europe and especially attractive tourist product of Podrinje touristgeographical region is timber rafting ${ }^{1}$ down the river Drina. Tourist arrangements can be one-day and multi-day with the possibility of rest and recreation along the river

\footnotetext{
${ }^{1}$ Timber raft is an unusual vessel built of wooden round wood with a capacity of about 15 people, lasts one day, with the possibility of sport fishing from the raft and enjoy the gastronomic offer of local specialties (http://www.turizam-bpk.ba/SplavarenjeDrinom.html)
} 
Drina. From Ustikolina to Goražde, tourists will discover hidden beauty, untouched nature, and an unforgettable adventure (http://www. turizambpk.ba/SplavarenjeDrinom.html).

Also, an important mention is certainly the ship "Vodeni Ćiro" made in the spirit of old steamships, which is irresistibly associated with the narrow-gauge Ćiro and sails the flooded route of the former railway. The ship has a capacity of 50 seats and it is possible to hold meetings and seminars in the saloon area. Vodeni Ciro sails through the unusual and beautiful ambiance of the canyon of the Drina-Lim lake, in the length of $50 \mathrm{~km}$, between Višegrad, Goražde, and Rudo.

Orlovača cave system is one of the most important speleological objects in our country. It is located on the hill of the same name in Sumbulovac, $1 \mathrm{~km}$ from the main road Sarajevo - Sokolac and belongs to the Podrinje tourist-geographical region (Bidžan, A., 2011). It is only $10 \mathrm{~km}$ away from Sarajevo, so the cave is located in excursion zones and has a favorable tourist-geographical position. One of the most important winter tourist centers, mount Jahorina is located only $25 \mathrm{~km}$ from the cave, which also increases its tourist attractiveness. In new research, in 2002, during the construction of the continuation of the tourist trail, whole skulls of bears and several different bones were found. In the same year, the cave was opened to tourists. The entrance to the Orlovača cave is located at 948 meters above sea level. It morphologically consists of three levels, the most interesting of which is the "Glavni Kanal"(Main Channel) about 1,000 m long, richly decorated with cave jewelry. This is currently the only part of the cave that is available for tourist visits in the length of $560 \mathrm{~m}$. Glavni Kanal (Main Channel) is rich in various types of well-preserved cave jewelry: stalactites, stalagmites, colorful saliva, and large massive cave pillars, which are quite common types of cave jewelry in Orlovača. Cave jewelry is of different colors. Accumulative forms, composed of larger crystals of sparkling calcite, are very common. In the entire cave system, morphologically the most impressive is the large hall "Galerija" (Gallery, the old name "Gora Romanija") $70 \mathrm{~m}$ long, $30 \mathrm{~m}$ wide, and $15-20 \mathrm{~m}$ high. Orlovača cave is an underground system that has not yet been fully speleologically explored, so it is possible to discover new channels, which is certainly suitable for the development of speleological and scientific-research tourism (http://www.sokolacturizam.net/index.php?option=com_content $\&$ view=article\&id=109\&Itemid=588\&lang=en).

Sutjeska National Park is located in the southeastern part of Bosnia and Herzegovina, on the main road Belgrade - Višegrad - Foča - Trebinje - Dubrovnik. From the east, it is closed by Pivska planina and the river Piva to Śćepan polje, and further along the Drina to the mouth of the river Sutjeska; to the west is the massif of the mountain Zelengora (2,014 m), connected with Lelija, and to the southeast the mountains: Maglić $(2,386 \mathrm{~m})$, Volujak and Bioč. It is located in the Podrinje and East Herzegovina touristgeographical region (Bidžan, A., 2011). The river Sutjeska flows through this area with several tributaries. The size of the national park is 17,350 ha. The most attractive area is the narrower part of the park, where the Perućica rainforest is located, which is unique in this area (1,291 ha). The Sutjeska National Park encompasses the wider Sutjeska River Basin area, including the strictly protected Perućica Reserve, as well as parts of the Maglić, Volujak, and Zelengora mountains. With the proclamation of this area as a national park in 1962, the most beautiful parts of three municipalities entered its borders: Foča, Gacko, and Kalinovik. Of the total area of the park, over $66 \%$ is covered by 
forests, and the rest consists of pastures, meadows, and barren lands above the upper limit of forests. Poor housing and difficult accessibility have long been the main reason why very few people had the opportunity to visit all these treasures, which nature has given them in abundance. In this area, there are exceptional specimens of fir, beech, and spruce with individual trees over $50 \mathrm{~m}$ high and with a real wealth of wood mass of over $1,000 \mathrm{~m}^{3} / \mathrm{ha}$. In this, almost inaccessible, the canyon of the river Perućica, where the human foot has hardly ever set foot, the volume, the height of the trees, and the beauty of the forests were unparalleled in the Dinarides. As a result of this discovery, the Government of the Republic of Bosnia and Herzegovina decided to exclude this area from regular use and in 1952, the Perućica rainforest was declared a strictly protected reserve, used exclusively for science and education, which is then certainly suitable for the development of scientific research and eco-tourism (http://ba.boell.org/sites/default/files/zastita_prirode_web.pdf).

\section{Tourist valorization of natural tourist potentials of Podrinje tourist- geographical region}

Evaluation of natural tourist potentials of Podrinje tourist-geographical region is a complex procedure of assessment of all indicators, which make tourist potential specific and unique, e.g tourist-geographical position, attractiveness, ambiance, compatibility, tourist attendance, etc., which are key in the development of individual-specific forms of tourism, to then create a complete tourist offer of this region. Based on the overall assessments of tourist indicators of natural tourist potential, the general tourist values of the natural tourist potentials of the Podrinje tourist-geographical region were obtained, based on which they were further ranked.

While conducting the tourist valorization, the author determined that in this touristgeographical region there are 14 geomorphological, 9 hydrographic, 3 climatic, and 3 vegetative touristically very attractive natural potentials, which can serve as a stable basis for the development of various specific forms of tourism. Regarding the spatial significance in the Podrinje region, there are 2 that are of international importance, 4 of national, and 23 of regional importance (Bidžan, A., 2015).

In the tourist valorization of geomorphological tourist potentials, the highest grade 4.6 was given to the mountain Jahorina and based on the following criteria: touristgeographical position, ambiance, attractiveness and uniqueness, and the lowest grade (4 - very good quality and very good market attractiveness ) was obtained from the criteria of compatibility and tourist attendance, which means that the tourist board must urgently do better marketing for this tourist pearl. The general tourist value of this mountain is high and amounts to 4.6, which means that it has international tourist significance (Table 2 ), but region should still work on improving roads and tourist offer, then the rating and attendance could be even higher (Bidžan, A., 2015).

In the tourist valorization of hydrographic tourist potentials, the highest grade 4.6 was given to the river Drina based on the following criteria: tourist-geographical position, ambiance, attractiveness, compatibility and uniqueness, and the lowest grade (4 - very good quality and very good market attractiveness) was derived from the criteria of the degree of utilization for tourist purposes, access to natural tourist potentials and tourist attendance, which means that the tourist community must urgently do better marketing for this tourist pearl. The general tourist value of this mountain is high and amounts to 
4.6, which means that it has international tourist significance (Table 2), but region should still work on improving roads and tourist offer, then the rating and attendance could be even higher (Bidžan, A., 2015).

Table 2: Natural tourist potentials of the Podrinje tourist-geographical region

\begin{tabular}{|c|c|c|c|c|c|c|c|c|c|c|c|c|c|}
\hline \multirow{2}{*}{\multicolumn{3}{|c|}{ Natural tourist potentials }} & \multicolumn{11}{|c|}{ TOURIST VALORIZATION } \\
\hline & & & 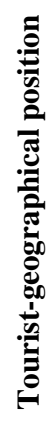 & 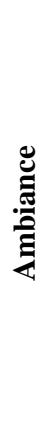 & 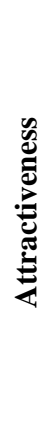 & 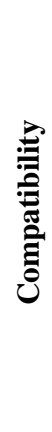 & 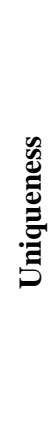 & 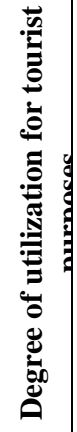 & $\frac{e_{0}^{2}}{4}$ & 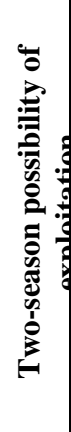 & 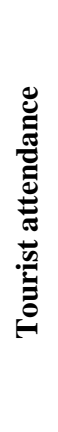 & 总 & 茂 \\
\hline \multirow{14}{*}{ 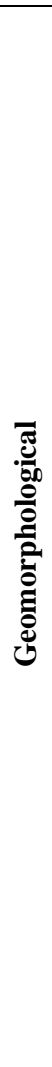 } & \multirow{7}{*}{$\begin{array}{c}\text { Mountai } \\
n s\end{array}$} & Jahorina & 5 & 5 & 5 & 4 & 5 & 4,5 & 4,5 & 4,5 & 4 & 4,6 & I \\
\hline & & Zelengora & 2,5 & 5 & 5 & 3 & 5 & 2 & 2,5 & 3 & 1,5 & 3,3 & $\mathbf{R}$ \\
\hline & & Volujak & 1,5 & 4 & 4 & 3 & 5 & 1 & 2 & 2 & 1 & 2,6 & $\mathbf{R}$ \\
\hline & & Vučevo & 1,5 & 4 & 4 & 3 & 5 & 1 & 2 & 2 & 1 & 2,6 & $\mathbf{R}$ \\
\hline & & Javor & 1,5 & 4 & 4 & 3 & 5 & 3 & 2,5 & 3 & 2,5 & 3,2 & $\mathbf{R}$ \\
\hline & & Sutjeska & 3 & 5 & 5 & 3,5 & 5 & 3 & 4 & 3 & 2,5 & $\mathbf{3 , 8}$ & $\mathbf{N}$ \\
\hline & & Lelija & 1,5 & 4 & 4 & 3 & 5 & 1 & 2 & 2 & 1 & 2,6 & $\mathbf{R}$ \\
\hline & $\begin{array}{l}\text { Gorges } \\
\text { and } \\
\text { canyons }\end{array}$ & Kanjon Drine & 3 & 4,5 & 4,5 & 3 & 5 & 1 & 3 & 2 & 1 & 3 & $\mathbf{R}$ \\
\hline & $\begin{array}{l}\text { Erosive } \\
\text { forms }\end{array}$ & $\begin{array}{l}\text { Zemljane } \\
\text { piramide }\end{array}$ & 2,5 & 5 & 5 & 3 & 5 & 2 & 2,5 & 3 & 1,5 & $\mathbf{3 , 3}$ & $\mathbf{R}$ \\
\hline & & $\begin{array}{l}\text { Golubovićka, } \\
\text { Rogatica }\end{array}$ & 3,5 & 4 & 5 & 3,5 & 5 & 1,5 & 2 & 1,5 & 1,5 & 3,1 & $\mathbf{R}$ \\
\hline & & $\begin{array}{l}\text { Ledenjača, } \\
\text { Foča }\end{array}$ & 2,5 & 4 & 4 & 4 & 5 & 1,5 & 2,5 & 1,5 & 1,5 & 2,9 & $\mathbf{R}$ \\
\hline & Caves & Orlovača, Pale & 4,5 & 5 & 5 & 4 & 5 & 3,5 & 3,5 & 3,5 & 3,5 & 4,2 & $\mathbf{N}$ \\
\hline & & $\begin{array}{l}\text { Govještica, } \\
\text { Rogatica }\end{array}$ & 3,5 & 4 & 5 & 3,5 & 5 & 1,5 & 2 & 1,5 & 1,5 & 3,1 & $\mathbf{R}$ \\
\hline & & $\begin{array}{l}\text { Mračna or Ban, } \\
\text { Rogatica }\end{array}$ & 2,5 & 4 & 4 & 4 & 5 & 1,5 & 2,5 & 1,5 & 1,5 & 2,9 & $\mathbf{R}$ \\
\hline \multirow{4}{*}{ 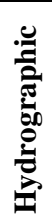 } & \multirow{4}{*}{ Rivers } & Drina & 5 & 5 & 5 & 5 & 5 & 4 & 4 & 4,5 & 4 & 4,6 & I \\
\hline & & Kolina & 4 & 3 & 2 & 3 & 3,5 & 1 & 5 & 2,5 & 2 & 2,8 & $\mathbf{R}$ \\
\hline & & Prača & 3 & 3 & 2 & 3 & 3,5 & 3 & 3 & 2,5 & 3 & 2,8 & $\mathbf{R}$ \\
\hline & & Ćehotina & 4 & 4 & 3 & 4 & 4,5 & 3,5 & 3,5 & 2,5 & 3,5 & 3,6 & $\mathbf{N}$ \\
\hline
\end{tabular}




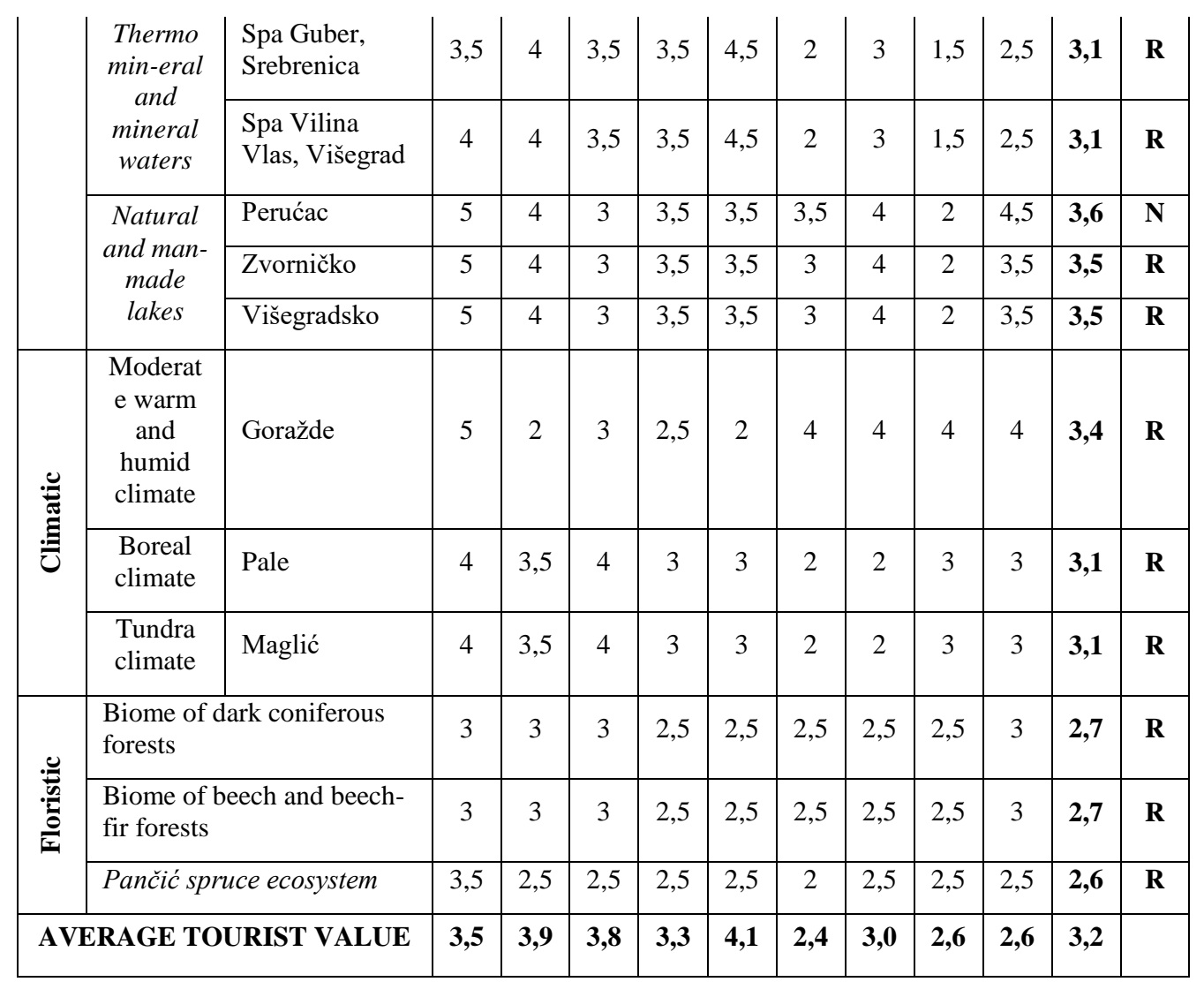

Legend: $\mathrm{R}$ - regional tourist significance, $\mathrm{N}$ - national tourist significance, I international tourist significance. Source: Bidžan, A., 2015.

One of the necessary and permanent tasks of Bosnia and Herzegovina's tourism policy, but also this region, should be careful and systematic monitoring of development trends in the international tourism market in terms of promotion and exploitation of natural tourism potentials for tourism purposes, without violating them. In that direction, Bosnia and Herzegovina, i.e its tourist-geographical regions, should develop its tourist products, which with such a great wealth of natural tourist potentials would be ideal for the development of numerous types of tourism (duration of stay, degree of mobility, nationality, etc.) and specific forms of tourism (sports-recreational, adventure, rural, eco-tourism, hunting, fishing, speleological, etc.). It is only when tourists, foreign and domestic, start visiting these natural tourist potentials that we can talk about their growth into tourist attractions, which would fill the budgets of local communities and thus improve furthermore balanced regional development of tourist-geographical regions of Bosnia and Herzegovina.

\subsection{Accommodation capacities}

Accommodation facility means a business facility operated by a caterer (legal or natural person registered to perform catering activities in a group of hotels) or a legal entity that is not a caterer, but under the conditions prescribed by law can perform catering 
activities for a caterer. As for the commercial tourist accommodation capacities of the Podrinje tourist-geographical region, they are quite modest, as we can see from the following table 3 .

Table 3: Commercial tourist accommodation capacities of the Podrinje touristgeographical region in 2018

\begin{tabular}{|c|c|c|c|}
\hline Place & Category & Objects & Capacity (number of beds) \\
\hline \multirow[t]{2}{*}{ Pale } & Hotels & 3 & 122 \\
\hline & Boarding houses & 1 & 38 \\
\hline Vlasenica & Hotels & 1 & 150 \\
\hline Bratunac & Motels & 1 & 25 \\
\hline Milići & Motels & 1 & 35 \\
\hline \multirow[t]{2}{*}{ Rogatica } & Hotels & 1 & 40 \\
\hline & Boarding houses & 1 & 6 \\
\hline Pale & Hotels & 14 & 569 \\
\hline \multirow[t]{2}{*}{ Sokolac } & Hotels & 1 & 64 \\
\hline & Boarding houses & 1 & 9 \\
\hline \multirow[t]{3}{*}{ East Sarajevo } & Hotels & 1 & 35 \\
\hline & Motels & 2 & 53 \\
\hline & Boarding houses & 1 & 20 \\
\hline Višegrad & Hotels & 3 & 364 \\
\hline \multirow[t]{2}{*}{ Srebrenica } & Motels & 1 & 40 \\
\hline & Hostels & 1 & 25 \\
\hline \multirow[t]{3}{*}{ Goražde } & Hotels & 1 & 29 \\
\hline & Boarding houses & 4 & 83 \\
\hline & Motels & 1 & 46 \\
\hline \multirow[t]{2}{*}{ Ustikolina } & Tourist resort & 1 & 15 \\
\hline & Boarding houses & 1 & 16 \\
\hline Prača & Tourist resort & 1 & 26 \\
\hline \multirow[t]{3}{*}{ Foča } & Hotels & 2 & 242 \\
\hline & Motels & 2 & 96 \\
\hline & Accommodations / camps & 15 & 1822 \\
\hline \multicolumn{2}{|r|}{ TOTAL } & 62 & 3.970 \\
\hline
\end{tabular}

Source: www.rzs.rs.ba; https://fzs.ba/wp-content/uploads/2020/06/BPK_2020.pdf

Tourist accommodation capacities in the Podrinje tourist-geographical region consist of 62 facilities: 27 hotels, 8 motels, 9 boarding houses, 1 hostel, 2 tourist resorts, and 15 camps with facilities with rooms for rent, a total of 3,970 beds, which is a very modest number according to the quality and scope of natural tourist potentials in this region, which could be valorized for tourism. 


\section{CONCLUSION}

Regardless of the specific form of tourism developed in the Podrinje touristgeographical region, tourism should fully take into account current and future economic, social and environmental effects, to take care of the needs of the local population, tourists, sectors, environment, and the destination itself. The principles of sustainability refer to the environmental, economic, and socio-cultural aspects of tourism development. To achieve long-term sustainability in this region, an appropriate balance must be established between all three dimensions. To preserve the pristine untouched nature of the Podrinje tourist-geographical region, the development of sustainable tourism should carry out the following: 1. Optimal use of natural resources that are a key element of tourism development, preserving important geo-ecological processes 2 . Respect of the socio-cultural authenticity of this region, preserving their built and cultural heritage and traditional values, and contributing to intercultural understanding and tolerance, 3. Ensure that economic activities are sustainable and long-term, and bring social and economic benefits to all participants with equitable distribution, including employment stability, opportunities to earn on social services in the community, helping to eradicate poverty, greater inclusion of women and youth, etc.

For the Podrinje tourist-geographical region to reach the level of development that would enable the development of sustainable nature-friendly tourism, a longer period of time is needed and this ongoing process requires constant monitoring of effects and introduction of necessary preventive and/or corrective measures. The goal of such tourism development would be primarily the protection of the natural environment, and at the same time, the quality of the tourist offer and the competitiveness of the Podrinje tourist-geographical region on the tourist market would increase, both regionally, nationally, and internationally.

\section{LITERATURE}

1. Atlas of the World for Primary and Secondary School (1998), Sejtarija, Sarajevo.

2. Bidžan, A. (2011): Turističko-geografsko rejoniranje kao osnova geografske regionalizacije Bosne i Hercegovine, Master's thesis defended at the Faculty of Science, University of Sarajevo, Documentation Fund of the Faculty of Science in Sarajevo, Sarajevo;

3. Bidžan A. (2012): Turističko-geografski rejoni Bosne i Hercegovine, Proceedings of the III Congress of Geographers of Bosnia and Herzegovina, Geographical Society in FB\&H, Sarajevo.;

4. Bidžan, A. (2015): Regionalni aspekt vrednovanja turističkih potencijala Bosne i Hercegovine, Doctoral dissertation defended at the Faculty of Science, University of Sarajevo, Documentation Fund of the Faculty of Science in Sarajevo, Sarajevo;

5. https://fzs.ba/wp-content/uploads/2020/06/BPK_2020.pdf

6. http://fzs.ba/index.php/popis-stanovnistva/popis-stanovnistva-2013/konacnirezultati-popisa-2013/

7. http://ba.boell.org/sites/default/files/zastita_prirode_web.pdf 
8. http://www.turizam-bpk.ba/SplavarenjeDrinom.html

9. http://www.sokolacturizam.net/index.php?option=com_content\&view=article\&id $=109 \&$ Itemid $=588 \&$ lang $=$ en

10. http://www.turizam-bpk.ba/SplavarenjeDrinom.html

11. http://www.logosfera.net/reka-drina-i-njen-sliv/

12. http://www.turizam-bpk.ba/page6.html

13. http://www.voders.org/index.php/slivovi/sliv-drine;

14. http://www.npsutjeska.net/stranica.phpid=51\& naziv=planine \&jez=bs

15. http://www.zone-2000.net/service/books_img/mag_vol_zel.pdf

16. http://www.jahorina.org/oc-jah.php

17. http://www.turizam-bpk.ba/page4.html

18. Lakušić, R. (1981): Klimatogeni ekosistemi Bosne i Hercegovine, Geografski pregled, No.25, Geographical Society of Bosnia and Herzegovina, Geographical Institute, Department of Geography, Faculty of Science in Sarajevo, Sarajevo.

19. Spatial Plan of Bosnia and Herzegovina, Phase "B" - valorization; Natural and cultural-historical values, Institute of Architecture, Urbanism and Spatial Planning of the Faculty of Architecture in Sarajevo, Sarajevo, 1980.

20. Spatial Plan of the Federation of Bosnia and Herzegovina for the period 2008-2028, Spatial Basis, Federal Ministry of Physical Planning, 2008.

21. Živojević, R. S. (2009): Goražde u prošlosti i danas / Ilovača predio kod Goražda, Economic-geographical and ethnographic observations, No.1, Goražde Cultural Center, Goražde. 